University of Pennsylvania Carey Law School

Penn Law: Legal Scholarship Repository

Faculty Scholarship at Penn Law

$12-4-2020$

\title{
A Babe in the Woods: An Essay on Kirby Lumber and the Evolution of Corporate Law
}

Lawrence Hamermesh

University of Pennsylvania

Follow this and additional works at: https://scholarship.law.upenn.edu/faculty_scholarship

Part of the Business Organizations Law Commons, Corporate Finance Commons, Law and Economics Commons, Legal History Commons, Legal Profession Commons, Litigation Commons, and the Securities Law Commons

\section{Repository Citation}

Hamermesh, Lawrence, "A Babe in the Woods: An Essay on Kirby Lumber and the Evolution of Corporate Law" (2020). Faculty Scholarship at Penn Law. 2235.

https://scholarship.law.upenn.edu/faculty_scholarship/2235

This Article is brought to you for free and open access by Penn Law: Legal Scholarship Repository. It has been accepted for inclusion in Faculty Scholarship at Penn Law by an authorized administrator of Penn Law: Legal Scholarship Repository. For more information, please contact PennlawIR@law.upenn.edu. 


\title{
A Babe in the Woods: An Essay on Kirby Lumber and the Evolution of Corporate Law
}

\author{
Lawrence A. Hamermesh ${ }^{1}$
}

\section{The Setting}

The account below parallels the content of an interview on November 8, 2019, in which my former colleague Professor Paul Regan guided a conversation with me about my career in corporate law, and the major themes and trends that emerged in the course of that career. What follows, however, is not anything close to a verbatim transcript of that interview; rather, it lays out in narrative prose the points I intended to cover, and mostly did cover, during the interview.

This is a personal, even self-centered, account. The rationale for that approach is that quite by chance, my career as a Delaware corporate law practitioner, law professor, and legislative drafter happened to coincide with an extended period (since 1976) of dramatic evolution of corporate law. At least in hindsight, I see in my own experience the emergence of trends and issues that have been and remain at the forefront of corporate law. I am grateful to Professor Regan for engaging in the conversation, to Professor Bruce Grohsgal for arranging the interview, and to the Pileggi family for sponsoring the long-standing and prestigious lecture series of which my interview was the most recent, but by no means most impressive, entry. ${ }^{2}$

\section{Introduction to the Practice of Corporate Law}

When I joined the Wilmington, Delaware law firm of Morris, Nichols, Arsht \& Tunnell in June of 1976 as a new associate fresh out of law school, I was escorted upon arrival to the office of S. Samuel Arsht, then regarded as a "dean" of the Delaware

\footnotetext{
${ }^{1}$ Professor Emeritus, Widener University Delaware Law School; Executive Director, University of Pennsylvania Carey Law School Institute for Law and Economics. The author gratefully acknowledges the excellent research assistance provided by Marina Masterson, University of Pennsylvania Carey Law School '21.

${ }^{2}$ The list of formidable presenters in this series is available at Past Lectures, DEL. J. CORP. L. OF WIDENER U. DEL. L. SCH. (2019), https://delawarelaw.widener.edu/files/resources/2019pileggimaterialsabout.pdf.
} 
corporate bar. Mr. Arsht (as I then thought of him) welcomed me graciously, and it became apparent that he had a puckish, good-humored twinkle in his eye: noting that I had just graduated from law school, he suggested that at this point I knew everything there was to know about the law. I assured him that, to the contrary, I had learned really nothing in law school, to which he replied that perhaps we were all in trouble then - or something like that.

In any event, I promptly got my first assignment: preparing a legal memo about estoppel relating to a pending statutory appraisal case, Bell v. Kirby Lumber Corp. ${ }^{3} \mathrm{I}$ dutifully completed the memo ${ }^{4}$ and did some other work on the post-trial and appellate briefing, but did not even begin to recognize the momentous issues of corporate law lurking in the case. One of those issues may be more familiar to students of corporate and securities law than the appraisal litigation I worked on: the short-form freezeout merger by which Santa Fe Industries acquired the minority shares of Kirby Lumber gave rise to federal litigation in which the United States Supreme Court famously ruled that allegations of fiduciary misconduct by the controlling stockholder failed to state a claim cognizable under SEC Rule 10b-5, but rather involved state law claims of breach of fiduciary duty that had to be presented in state court. ${ }^{5}$ Had the Supreme Court come out the other way, the explosion of fiduciary duty litigation that marked the takeover era of the 1980s and swallowed up me and my colleagues at the Delaware Bar would likely have occupied a very different venue, and my own legal career would have turned out very differently. ${ }^{6}$

\footnotetext{
${ }^{3}$ Bell v. Kirby Lumber Corp., 395 A.2d 730 (Del. Ch. 1978), aff'd, 413 A.2d 137 (Del. 1980).

${ }^{4}$ The memo analyzed whether our client should be estopped to present an expert opinion about the value of Kirby's assets that was different and substantially lower than the valuation presented in the information statement that accompanied the freezeout merger that gave rise to the proceeding. Our position prevailed, largely because of the view that a party's statement or contention cannot limit the valuation discretion or judgment of the tribunal. Id. at 737-739.

${ }^{5}$ Green v. Santa Fe Indus., Inc., 430 U.S. 362 (1977).

${ }^{6}$ See Jack B. Jacobs, Fifty Years of Corporate Law Evolution: A Delaware Judge's Retrospective, 5 HARV. BUS. L. REV. 141, 144-45 (2015).
} 


\section{Premiums, Discounts, and Market Price}

But I was at best dimly aware of these matters at the time. I was only slightly more cognizant of other lurking issues in the case, issues that would grow into matters of raging contention among scholars, practitioners and judges of corporate law. These issues stemmed from the oddity that Kirby Lumber, a forest products manufacturer with extensive timber holdings in East Texas and Louisiana, could have assets deemed worth $\$ 456$ per share on a liquidation basis, but at the same time generate earnings that implied a value of only about $\$ 120$ per share. ${ }^{7}$ What could possibly explain this enormous disparity? And absent a satisfactory explanation, why wouldn't the controlling stockholder, as a rational business actor, simply liquidate or sell the company rather than continue to operate it? Conversely (and this is the position we took on behalf of the respondent), if Kirby was going to continue to be operated as it had been, on a sustained yield forestry principle, why should a stockholder be entitled to an appraisal award that included any value attributable to a hypothetical liquidation or sale that was not going to occur?

The court-appointed appraiser in the Kirby Lumber appraisal case, ${ }^{8}$ whose decision was upheld by the Delaware Court of Chancery and the Delaware Supreme Court, took something of a Solomonic approach to these questions: ${ }^{9}$ he declined to place primary weight on the liquidation value of Kirby's assets because precedent dictated that the dissenters' shares be valued as a proportional interest in a going concern, rather than as a liquidating concern; he likewise declined to place primary weight on the estimated value of Kirby's earnings potential; and instead he assigned a sixty percent weight to earnings value, and a forty percent weight to asset value because, as the Chancellor

\footnotetext{
${ }^{7}$ Kirby Lumber, 395 A.2d at 733.

${ }^{8}$ Rodman Ward, Jr., a formidable litigator and leading figure in the Delaware Bar, who co-founded the Wilmington, Delaware, branch of the international law firm Skadden, Arps, Slate, Meagher \& Flom, LLP.

${ }^{9}$ At the time of the Kirby Lumber appraisal litigation, the Delaware courts rigorously adhered to the so-called "Delaware block method" of determining the fair value of shares being appraised - in which several valuation factors were assessed and assigned weights. See, e.g., Lawrence A. Hamermesh \& Michael L. Wachter, The Fair Value of Cornfields in Delaware Appraisal Law, 31 J. CORP. L. 119, 124 (2005).
} 
explained, asset value "constitutes a substantial benefit of which a minority stockholder should not be deprived because of a merger," "even though [Kirby Lumber] depends upon its manufacturing capabilities for its means of income." 10

That resolution may have put the Kirby Lumber appraisal case to rest, but even though I did not fully appreciate it at the time, the asset value/earnings value disparity foreshadowed some critically important debates in law and economics. For one thing, that disparity appears in hindsight to have been the leading edge of a phenomenon that starkly characterized the most celebrated takeover bids in the early 1980s: the apparent willingness of takeover bidders to offer enormous premiums over share market prices, especially for natural resource companies, like Unocal, Gulf Oil, Phillips Petroleum, and more. ${ }^{11}$ That phenomenon introduced me to the teachings of law and economics, albeit what was a somewhat naïve application of the discipline. The leading practitioners of that discipline, confident in the market's judgment about the value of a widely traded stock, asserted that any tender offer at a premium to market price must be wealth enhancing. ${ }^{12}$

${ }^{10}$ Kirby Lumber, 395 A.2d at 741.

${ }^{11}$ See, e.g., G. Christian Hill, Jonathan Dahl \& Edwin A. Finn, Jr., Mesa's Pickens and Partner Plan to Seek 10\% of Phillips Petroleum at $\$ 60$ a Share-Bid is Regarded as First Step by Oilman to Gain Control of Oklahoma Competitor, WALL ST. J., Dec. 5, 1984 (reporting that Mesa's bid for Phillips Petroleum constituted a thirty-one percent premium over the share price as of two days prior); Mark Potts \& Peter Behr, Gulf Accepts Bid by Socal; Merger Would Be Largest, WASH. Post, Mar. 6, 1984, at A1 (reporting that Gulf accepted a bid of $\$ 80$ per share, while its stock had only been trading at \$57.25 per share two months earlier); Nancy Rivera \& Debra Whitefield, Unocal Board Rejects Mesa Takeover Bid; Pickens Group Says it has Already Lined Up Needed Financing, L.A. TIMES, Apr. 15, 1985, at 1 (reporting that Unocal shares were trading at less than $\$ 34$ before the bidder made its offer of $\$ 54$ ).

12 Frank H. Easterbrook \& Daniel R. Fischel, The Proper Role of a Target's Management in Responding to a Tender Offer, 94 HARV. L. REV. 1161, 1165-75 (1981) (arguing that markets are in fact efficient, and premium tender offers benefit shareholders of the target corporation, the bidder, and the industry by reducing agency costs). This assertion, of course, failed to reckon with the two-tiered/partial takeover bid tactic that would be employed most notably by Mesa Petroleum in its purported quest to acquire Unocal. In that bid form, the overall value of the bid is obscured by any uncertainty about the value to be paid in any second-step merger, and in any event the structure of the bid substantially vitiates any voluntariness and market reliability in stockholders' responses to the bid. See Stephen M. Bainbridge, UNOCAL at 20: Director Primacy in Corporate Takeovers, 31 DEL. J. CORP. L. 769, 796-97 (2006) (explaining that the mere possibility of a less favorable second-step payout coerces shareholders to tender); see also Robert A. 
As a corollary, they claimed, any action by directors - motivated necessarily, they said, by personal interest in preserving their positions - to impede the consummation of such wealth-enhancing transactions must be allowed, if at all, only upon a substantial demonstration by the directors that their actions were directed toward economic benefit to the target - a burden not unlike that required by the rigorous "entire fairness" standard of judicial review of transactions tainted by conflict of interest. ${ }^{13}$

These law and economics-based claims accompanied another enduring response to the conundrum posed by the Kirby Lumber value disparity: namely, that this disparity existed in significant part because of agency costs - costs due to managerial inefficiency arising from disloyalty, negligence, or lack of diligence, or some combination of these flaws. ${ }^{14}$ It was further posited that a vibrant market for corporate control - in the form of tender offers undeterred by defensive devices adopted by target company directors - was a critical mechanism for reducing those agency costs, thereby enhancing social and shareholder welfare and reducing the disparity between share market prices and the underlying value of firms. ${ }^{15}$

Prentice, Front-End Loaded, Two-Tier Tender Offers: An Examination of the Counterproductive Effects of a Mighty Offensive Weapon, 39 CASE W. RES. L. REV. 389, 395-97 (1988-89).

${ }^{13}$ Easterbrook \& Fischel, supra note 12, at 1201-03 (proposing a rule of "managerial passivity" where directors are barred from all defensive actions except ordinary business and press releases); see also Frank H. Easterbrook \& Gregg A. Jarrell, Do Targets Gain From Defeating Tender Offers?, 59 N.Y.U. L. REV. 277 (1984) (presenting evidence to argue that shareholders and markets more largely suffer when managers defeat tender offers); Weinberger v. UOP, Inc., 457 A.2d 701, 710 (Del. 1983) ("The requirement of fairness is unflinching in its demand that where one stands on both sides of a transaction, he has the burden of establishing its entire fairness, sufficient to pass the test of careful scrutiny by the courts.").

${ }^{14}$ Easterbrook \& Fischel, supra note 12, at 1168-70 (positing that agency costs decrease the trading value of shares); see generally, Michael C. Jensen \& William H. Meckling, Theory of the Firm: Managerial Behavior, Agency Costs and Ownership Structure, 3 J. FIN. ECON. 305 (1976) (showing that the agency relationship incentivizes managers to act in their own interest, affecting the firm's value).

${ }^{15}$ Easterbrook \& Fischel, supra note 12, at 1173-74. The idea is that agency costs are exacerbated by the free-riding tendencies among shareholders. Easterbrook \& Fischel argue that takeovers help reduce agency costs because the bidder assumes a high enough 
Needless to say, corporate managers and their advocates were having none of this. They maintained that actions to frustrate unsolicited tender offers at a premium to market price were justifiable because market prices did not reliably reflect firm value and that there were numerous explanations beyond agency costs why a bidder might offer a substantial premium over market price to acquire an entire company. ${ }^{16}$ This camp had its own corollary: director actions to frustrate an unsolicited takeover bid should be judged in the courts the same way as any other corporate decision, i.e., under the deferential business judgment rule. ${ }^{17}$

Corporate Constituencies and the Universal Shareholder

number of shares to benefit from monitoring managers. Moreover, the unfettered threat of takeover would incentivize managers to self-monitor and reduce agency costs.

${ }^{16}$ See Reinier Kraakman, Taking Discounts Seriously: The Implications of "Discounted" Share Prices as an Acquisition Motive, 88 COLUM. L. REV. 891, 893-901 (1988) (cataloguing explanations for takeover premiums); see also Martin Lipton, Takeover Bids in the Target's Boardroom, 35 BUS. LAW. 101, 106-09 (1979) (presenting evidence that rejecting tender offers frequently does benefit shareholders in the long run).

The tension within Delaware case law about the valuation significance to attach to share market prices surely merits its own article. Compare Chicago Corp. v. Munds, 172 A. 452, 455 (1934) ("Even when conditions are normal and no economic forces are at work unduly to exalt or depress the financial hopes of man, market quotations are not safe to accept as unerring expressions of value. The relation of supply to demand on a given day as truly affects the market value of a stock as it does of a commodity; and temporary supply and demand are in turn affected by numerous circumstances which are wholly disconnected from considerations having to do with the stock's inherent worth."), with Dell, Inc. v. Magnetar Glob. Event Driven Master Fund Ltd., 177 A.3d 1, 24 (Del. 2017) ("[T]he efficient market hypothesis long endorsed by this Court ... teaches that the price produced by an efficient market is generally a more reliable assessment of fair value than the view of a single analyst, especially an expert witness who caters her valuation to the litigation imperatives of a well-heeled client."). The tension may not reflect contradiction, however: one could determine "fair value" based on a stock price generated in an informationally efficient market, yet recognize that it is at best an imperfect (and therefore perhaps incorrect) proxy due to noise trading or some other form of market failure. Moreover, a board of directors could conclude that even a bid in excess of a fundamentally accurate share market price could be inadequate if an even higher sale price could be achieved through a bid premised on more robust synergies.

${ }^{17}$ Lipton, supra note 16, at 115-16 ("[T] he policy considerations are overwhelmingly in favor of [the business judgment rule]"). 
When the Delaware Supreme Court confronted and resolved the doctrinal battle in its 1985 opinion in Unocal Corp. v. Mesa Petroleum, Inc., ${ }^{18}$ it opted for an ostensibly middle ground, acknowledging director authority to resist takeover bids but promising some form of enhanced judicial scrutiny. ${ }^{19}$ In so doing, however, it threw fuel on the fire of yet another persistent struggle in corporate law that was implicit in the Kirby Lumber case. To explain: Unocal famously stated that directors evaluating a takeover bid should consider, among other things, "the [bid's] impact on 'constituencies' other than shareholders (i.e., creditors, customers, employees, and perhaps even the community generally)." ${ }^{20}$ That statement excited the ardor of those who had urged that directors can and should manage the corporation with a view not only toward maximizing shareholder financial wealth, but as well toward advancing the interests of others affected by corporate conduct. ${ }^{21}$

As thus framed, the debate about the purpose of the corporation has played out as a battle between the interests of shareholders and the interests of other constituencies affected by corporate conduct. Indeed, that putative dichotomy was what the Delaware Supreme Court articulated in Unocal and reinforced in Revlon, where it declared that maximizing the current financial value of the corporation's shares is the primary goal of the board of directors, to the exclusion of consideration of any other constituencies, when

${ }^{18}$ Unocal Corp. v. Mesa Petroleum, Inc., 493 A.2d 946 (Del. 1985).

${ }^{19} \mathrm{Id}$. at 955 ("If a defensive measure is to come within the ambit of the business judgment rule, it must be reasonable in relation to the threat posed."). In hindsight, however, what thus might have appeared as an at least moderately robust approach to judicial review evolved into an approach that is rhetorically distinct but substantively similar to the business judgment rule. See Paul Regan, What's Left of Unocal?, 26 DEL. J. CORP. L. 947, 967-68 (2001) (arguing that Delaware case law has "dramatically expanded the scope of 'threats' justifying defensive responses under Unocal," weakening the enhanced judicial scrutiny of defensive actions).

${ }^{20}$ Unocal, 493 A.2d at 955.

${ }^{21}$ See, e.g., Margaret M. Blair \& Lynn A. Stout, A Team Production Theory of Corporate Law, 85 VA. L. REV. 247, 308 (1999) (arguing that Unocal "squarely rejects shareholder primacy in favor of the view that the interests of the 'corporation' include the interests of nonshareholder constituencies"); see generally, Lipton, supra note 16, at 105-06 (supporting the idea that corporations are responsible to stakeholders other than shareholders). 
selling a company. ${ }^{22}$ Driven to its logical conclusion, and further reinforced in the $e$ Bay opinion of the Court of Chancery, ${ }^{23}$ maximization of stockholder financial wealth is the essence of stockholder primacy and the purpose that all corporate action must serve. ${ }^{24}$

I resist only part of that conclusion. I fully accept the concept of stockholder primacy that posits that the interests of stockholders are what the board of directors is charged with serving. Any contrary notion that directors can or should simultaneously serve any conflicting interests of non-stockholder constituencies is largely illusory in any event, even where a governing statute purports to enable directors to consider such other interests: how seriously can one take such a statute when the only constituency within the corporation with the power to vote on the election of directors is the stockholders? ${ }^{25}$ Given that allocation of voting power, how likely is it that directors will address and

\footnotetext{
${ }^{22}$ Revlon, Inc. v. MacAndrews \& Forbes Holdings, Inc., 506 A.2d 173, 182 (Del. 1986) ("[C]oncern for non-stockholder interests is inappropriate when an auction among active bidders is in progress, and the object . . . [is] to sell it to the highest bidder.").

23 eBay Domestic Holdings, Inc. v. Newmark, 16 A.3d 1, 34 (Del. Ch. 2010) (confirming that directors of for-profit corporations must prioritize "the value of the corporation for the benefit of its stockholders" over interest in community welfare and philanthropy); see Leo E. Strine, Jr., The Dangers of Denial: The Need for a Clear-Eyed Understanding of the Power and Accountability Structure Established by the Delaware General Corporation Law, 50 WAKE FOREST L. REV. 761, 776-77 (2015) (referring to eBay as "hornbook law" that acting in an interest separate and other from stockholder wealth is a breach of fiduciary duty). But see Lyman Johnson, Pluralism in Corporate Form: Corporate Law and Benefit Corps, 25 REGENT U. L. REV. 270, 274-75 (arguing that because the $e B a y$ opinion cites no precedent supporting its language about shareholder primacy, the issue is "legally unsettled").

${ }^{24}$ See Principles of Corporate Governance $§ 2.01$ (AM. LAW InST. 1994) (“'A] corporation ... should have as its objective the conduct of business activities with a view to enhancing corporate profits and shareholder gain," limited by the duty to act lawfully, the right to act ethically, and the authority to serve nonshareholder constituents if it benefits shareholders in the long run).

${ }^{25}$ See Frank H. Easterbrook \& Daniel R. Fischel, Voting in Corporate Law, 26 J. L. \& ECON. 395, 403 (1983) (noting that managers' knowledge that shareholders have exclusive voting power in elections "tends to cause managers to act in shareholders' interest in order to advance their own careers and to avoid being ousted"); Julian Velasco, Shareholder Ownership and Primacy, 2010 U. ILL. L. REV. 897, 909-10 (2010) (explaining that shareholders have significant, albeit underestimated, influence over directors because of their voting power).
} 
satisfy interests of non-stockholder groups when those interests conflict with the interests of stockholders?

Accepting stockholder primacy, however, only answers half the question of corporate purpose, because even if it tells us that the interests of stockholders are paramount, it does not tell us how to define what those interests actually are. This latter inquiry brings me back, again, to Kirby Lumber. If Kirby Lumber's operating policy of harvesting timber only on a sustained yield basis was grounded in considerations of environmental impact, it at least raised the possibility that the company was being managed with the interests of the larger community, and not just the stockholders, in mind. Perhaps as a result of that management approach, the company as a going concern was not achieving the maximum value to stockholders that would have been generated by a less environmentally friendly decision to clear-cut and sell off the company's timber reserves. In short, the puzzling value disparity noted earlier may have stemmed at least in part from a managerial orientation that was suboptimal from the standpoint of the hypothetical stockholder focused only on financial returns. ${ }^{26}$

One possible response to this conundrum is that Kirby Lumber had a controlling stockholder, Santa Fe Industries, whose economic interest, coupled with its control, could be counted on to assure that Kirby Lumber was managed in the interest of stockholders. That response unravels, however, when one recognizes that Santa Fe Industries itself was a publicly held firm whose managers may not have been sufficiently accountable to stockholders to assure that stockholder wealth would be the guidepost for its management of Kirby Lumber. In other words, a failure to maximize Kirby Lumber's value may have been just another instance of mismanagement due to insufficient accountability to shareholders.

This line of thinking, however, masks an unstated, and incorrect, assumption. In short, the hypothetical stockholder who cares only about maximizing the current financial value of her investment is just that - hypothetical - and a model of corporate law and governance that assumes that such a person not only exists, but predominates, is simply unrealistic. It may be unrealistic in a usefully convenient way: it distills any

${ }^{26}$ See supra note 15 and accompanying text. 
inquiry about corporate decision-making down to a more or less manageable question of finance - namely, what decision today will result in the greatest current value of the corporation's shares? But the millions of actual human beings whose capital is invested in corporate stock do not consider that question dispositive. ${ }^{27}$ For one thing, the stockholder owning shares of Kirby Lumber will not want Kirby to clear cut its forests, even if that would maximize the value of those Kirby shares, if the result would be to impose an even greater offsetting loss in value of shares that same person owned in a company in the business of managing a resort that depended on an idyllic view of Kirby's woodlands. Negative externalities imposed by corporate behavior hit the pocketbooks of other corporations, and given widely practiced diversification of share ownership, ${ }^{28} \mathrm{a}$ holder of Corporation A's shares, even if motivated by purely financial considerations, will not necessarily support value-maximizing conduct by A that imposes offsetting impairment of the value of that holder's shares of Corporations B, C, and D. ${ }^{29}$

But the problem goes well beyond purely financial externalities and portfolio diversification. For the hypothetical, current share value-focused stockholder, clearcutting the Kirby forests and pocketing the proceeds might have been the best strategy for the board of directors to embrace. But the real human beings who were the ultimate investors in Kirby Lumber may have attached value to entirely different considerations.

\footnotetext{
${ }^{26}$ Lynn Stout's The Shareholder Value Myth (2012) points out that shareholders have varying interests besides maximizing current value. Indeed, short-term investors may have the traditional interest in maximizing firm value now, but long-term shareholders may want the company to invest in building talent, product development, and reputation. $I d$. at 69. And, as Stout argues, many individuals are willing to forego some profit in the interest of ethics and social responsibility.

${ }^{27}$ See Richard A. Brealey, Stewart C. Myers \& Franklin Allen, Principles of CORPORATE FINANCE 178-79 (10th ed. 2011) (discussing the value and impact of diversification, and noting that "[m]ost investors do not put all their eggs into one basket: They diversify").

${ }^{29}$ See Stout, supra note 21, at 307 (arguing that shareholders who are highly diversified may not be interested in immediate maximization of the firm's value if it threatens the value of other investments); see generally Robert G. Hansen \& John R. Lott, Jr., Externalities and Corporate Objectives in a World with Diversified

Shareholder/Consumers, 31 J. Fin. \& QUANTITATIVE ANALYSIS 43 (1996) (showing that diversified stockholders should disfavor value maximization by one firm and instead favor portfolio value maximization).
} 
They may have strongly preferred, for psychic and perhaps even financial reasons, that Kirby Lumber limit its timber harvest so that, without sacrificing at least some level of financial returns, the company's forest lands would continue to serve as carbon sinks and viable habitat for countless species, as well as a sustainable source of useful timber far into the future. ${ }^{30}$

In these respects, then, holders of corporate shares are "universal" owners, with interests extending well beyond - and sometimes in opposition to - admittedly widely shared interests in maximizing the profit of any single corporation. ${ }^{31}$ Recognizing this diversity of interests no doubt does complicate corporate decision-making: any candid assessment must acknowledge that these diverse interests cannot be measured or accommodated with even a modicum of precision. It also must be acknowledged, on the other hand, that the broad deference of the business judgment rule has undoubtedly tolerated, perhaps even masked, managerial behavior accompanied by lip service to maximizing shareholder wealth but really designed to serve interests other than stockholder wealth maximization. ${ }^{32}$ The Business Roundtable's controversial declaration

\footnotetext{
${ }^{29}$ See Sustainable Signals: Individual Investor Interest Driven by Impact, Conviction and Choice, Morgan Stanley Inst. Sustainable InVESTING, 3-4 (2019), https://www.morganstanley.com/pub/content/dam/msdotcom/infographics/sustainableinvesting/Sustainable_Signals_Individual_Investor_White_Paper_Final.pdf(finding that eighty-five percent of surveyed American stockholders are interested in investing in companies that pursue social and/or environmental objectives); Robert G. Eccles \& Svetlana Klimenko, The Investor Revolution, HARV. BUS. REV. (2019), https://hbr.org/2019/05/the-investor-revolution (showing that investing firms are increasingly concerned with the sustainability practices of the corporations they invest in).

${ }^{30}$ A leading exponent of this perspective is The Shareholder Commons, a group spearheaded by my former law partner Rick Alexander, and on whose advisory board I serve. THE SHAREHOLDER COMMONS (2020), https://theshareholdercommons.com.

${ }^{31}$ See Einer Elhauge, Sacrificing Corporate Profits in the Public Interest, 80 N.Y.U. L. REV. 773, 770-72 (2005) (arguing that the business judgment rule provides managers the "discretion" to sacrifice current profits for the public interest because managers can almost always claim their public-minded actions are directed toward long-term profitability); Sarah E. Light, The Law of the Corporation as Environmental Law, 71 STAN. L. REV. 137, 181-85 (2019) (describing the business judgment rule as a "safe harbor" for directors to promote environmental policies); see also Janet E. Kerr, Sustainability Meets Profitability: The Convenient Truth of How the Business Judgment Rule Protects a Board's Decision to Engage in Social Entrepreneurship, 29 CARDOZO L.
} 
in 2019 can only encourage managers of large corporations to take advantage of that flexibility. ${ }^{33}$ And the advent of the public benefit corporation enables businesses to promote a public purpose overtly instead of having to justify such conduct with lip service to stockholder wealth maximization. ${ }^{34}$ By requiring a public purpose to be set forth explicitly in the corporation's governing documents and requiring the corporation to report regularly on how it has attempted to serve that purpose ${ }^{35}$ thereby bringing publicregarding managerial action into public view, the benefit corporation structure may reduce the risk that self-serving managerial behavior will masquerade as attention to public purpose.

\section{Stockholder Litigation and the Populism Canard}

Stockholder litigation - specifically shareholder class actions, appraisal cases, and derivative suits - is a more traditional check on managerial misconduct. Indeed, the

REV. 623, 634-35 (2007) (going a step further to argue that directors are not only protected by the business judgment rule, but also have a duty to be informed about social entrepreneurship and consider environmental sustainability in their decision making).

32 Bus. Roundtable, Statement on the Purpose of A Corp. (Aug. 2019), https://opportunity.businessroundtable.org/ourcommitment (declaring that the purpose of corporations is to serve all stakeholders, not just shareholders, with an emphasis on longterm value); see also Richard Henderson \& Patrick Temple-West, Group of US Corporate Leaders Ditches Shareholder-First Mantra, FIN. TIMES (Aug. 19, 2019), https://www.ft.com/content/e21a9fac-c1f5-11e9-a8e9-296ca66511c9 (discussing the Roundtable's statement as a "significant departure from the bedrock belief" of shareholder primacy, and identifying policymakers and directors who support such a shift); Martin Lipton, Steven A. Rosenblum, \& Karessa L. Cain, Thoughts for Boards of Directors in 2020, HARV. L. SCH. F. CORP. GOVERNANCE (Dec. 10, 2020), https://corpgov.law.harvard.edu/2019/12/10/thoughts-for-boards-of-directors-in-2020 (pointing out to directors that the business judgment rule protects them in acting on behalf of stakeholders and advocating for the Business Roundtable's statement).

${ }^{33}$ See generally William H. Clark, Jr. \& Elizabeth K. Babson, How Benefit Corporations are Redefining the Purpose of Business Corporations, 38 WiLliAm MitCHELL L. REV. 817 (2012) (surveying the policies behind and key features of benefit corporations); Model BENEFIT CORPORATION LEGISLATION $§ 101 \mathrm{cmt}$. (B LAB Apr. 17, 2017) (explaining that public benefit corporations "operate with a corporate purpose broader than maximizing shareholder value and a responsibility to consider the impact of its decisions on all stakeholders, not just shareholders").

${ }^{35}$ E.g., 8 Del. C. $\S \S 362(a), 366(b)$. 
managerial agency costs narrative noted above has nurtured a perception among many academics that stockholder litigation is an essential mechanism to protect a class of persons (investors) who are relatively weak and vulnerable to abuse by corporate managers. ${ }^{36}$ How, then, could a liberal, social justice-oriented lawyer like me be content to defend controlling stockholders, directors and takeover targets in litigation brought to protect that relatively weak and vulnerable constituency?

My response is that unlike classes of consumers or racial or ethnic identity groups, stockholders are not, as a class, oppressed victims of corporate conduct. In fact, any populist analogy that would view investors in that light strikes me as offensive when invoked on behalf of stockholders, like me, who enjoy substantial wealth and privileged status and upbringing. Stockholder litigation is largely a dry affair, with little at stake beyond marginal differences of opinion about, and impacts on, financial worth. ${ }^{37}$ The fact that such marginal differences, in the context of publicly traded companies, amount to millions or sometimes even billions of dollars in the aggregate, makes stockholder class

\footnotetext{
${ }^{35}$ See Cohen v. Beneficial Indus. Loan Corp., 337 U.S. 541, 548 (1949) (declaring shareholder derivative suites as the "chief regulator of corporate management"); John C. Coffee, Jr. \& Donald E. Schwartz, The Survival of the Derivative Suit: An Evaluation and a Proposal for Legislative Reform, 81 COLUM. L. REV. 261 (1981) (proposing legislation to bolster shareholder litigation as a primary mechanism of corporate governance); Donald E. Schwartz, In Praise of Derivative Suits: A Commentary on the Papers of Professors Fischel and Bradley, 71 CORNELL L. REV. 322, 323 (1986) (arguing that shareholder litigation "profoundly affect[s] the conduct of corporate managers); Randall Thomas \& Robert B. Thompson, The New Look of Shareholder Litigation: AcquisitionOriented Class Actions, 57 VAND. L. REV. 133, 143 (2004) (explaining how derivative actions "have historically played key roles in checking . . managerial abuses").

${ }^{36}$ Indeed, shareholder litigation often involves disputes over just a couple dollars per share. See, e.g., Cede \& Co. v. Technicolor, Inc., 884 A.2d 26 (Del. 2005) (decades of litigation, including six appeals to the Delaware Supreme Court, attempting to dispute the share value price with the value only fluctuating within a range of \$21.98 to \$28.41); Weinberger v. UOP, Inc., 457 A.2d 701 (Del. 1983) (challenging a merger in which the controlling stockholder acquired the minority shares for $\$ 21$ per share when they might have been willing to pay up to \$24 per share); Revlon, Inc. v. MacAndrews \& Forbes Holdings, Inc., 506 A.2d 173 (Del. 1986) (finding a breach of fiduciary duties where directors accept a tender offer of $\$ 57.25$ per share instead of $\$ 56.25$, which was less accounting for the time value of money).
} 
action litigation viable, but at the same time it creates agency costs and pathologies in the way stockholder litigation is conducted. ${ }^{38}$

For example, while still in private practice I represented defendants in a stockholder derivative action on behalf of a Delaware corporation but brought in a West Virginia state court, where the claim was that the directors' negligence was responsible for cost overruns on a new manufacturing facility. ${ }^{39}$ Unlike the vast majority of Delaware corporations, this corporation's certificate of incorporation for some unknown reason failed to include a provision eliminating director monetary liability for lack of care. Such a provision might have avoided the litigation, but the case went forward, at considerable cost to the corporation (through advancement of defense costs). Those out of pocket costs, moreover, were not the most debilitating: the reaction of management, before the case settled, was to bend over in contortions to avoid taking any action or responsibility, lest they elicit even more claims of negligence and risks of liability. ${ }^{40}$ In short, derivative litigation can impose costs on the corporation - and indirectly its stockholders - just as easily, if not more frequently, than it can achieve any benefits to the corporation.

In this century, there have been several waves of stockholder litigation that were widely viewed as abusive and inefficient. One such wave featured stockholder class actions involving mergers negotiated and approved at arm's length, which were

37 See generally Coffee \& Schwartz, supra note 35, at 283 (“[A] derivative action evokes a response of group loyalty, so that even a 'maverick' director may feel compelled to close ranks and protect his fellows from the attack of the 'strike suiter."'); John C. Coffee, Jr., Understanding the Plaintiff's Attorney: The Implications of Economic Theory for Private Enforcement of Law Through Class and Derivative Actions, 86 ColuM. L. REV. 669, 714 (1986) ("Often, the plaintiff's attorneys and the defendants can settle on a basis that is adverse to the interests of the plaintiffs.").

38 See State ex rel. Elish v. Wilson, 434 S.E.2d 411 (1993).

39 The potential to generate excessive precaution costs is a significant element of the pathologies that can arise from aggregate shareholder litigation. See Steven M.

Bainbridge, Why a Board? Group Decisionmaking in Corporate Governance, 55 VAND. L. REV. 1, 50 (2002) (pointing out that "[s] hareholder litigation encourages directors to be risk averse," which increases costs because of suboptimal decision making and additional monitoring needs); Ehud Kamar, Shareholder Litigation Under Indeterminate Corporate Law, 66 U. CHICAGO L. REV. 887, 895-96 (explaining that the risk of liability from shareholder litigation causes directors to spend high sums on legal advice and act too cautiously in business decisions). 
challenged under Revlon, despite the absence of conflict of interest, due to alleged shortcomings in the sale process. ${ }^{41}$ Largely settled through supplemental disclosure and payment of hefty attorney's fees, with no recovery by the stockholder class members, ${ }^{42}$ these cases proliferated ${ }^{43}$ until reined in by more stringent standards for approval of disclosure-only settlements, ${ }^{44}$ by forum selection bylaws that limited multi-forum litigation pressures, ${ }^{45}$ and by increased doctrinal reliance on the cleansing effect of stockholder voting approval. ${ }^{46}$ Another wave involved Delaware statutory appraisal

${ }^{40}$ Lawrence A. Hamermesh \& Michael L. Wachter, The Importance of Being Dismissive: The Efficiency Role of Pleading Stage Evaluation of Shareholder Litigation, 42 J. CORP. L. 597, 600 (2017) (citing references to a "growing tide of litigation" exacting a "merger tax" "ultimately borne by shareholders and collected by the plaintiffs" class action bar").

${ }^{41}$ Id., citing Matthew D. Cain \& Steven M. Davidoff Solomon, A Great Game: The Dynamics of State Competition and Litigation, 100 Iowa L. REV. 465, 478 tbl. III (2015); see Matthew D. Cain \& Steven Davidoff Solomon, Takeover Litigation in 2015, 4-5 (Jan. $16,2016)$ (unpublished manuscript) (on file with Berkeley Center for Law, Business and the Economy), https://papers.ssrn.com/sol3/papers.cfm?abstract_id=2715890 (showing that only $3.8 \%$ of settlements include non-disclosure elements and tracking attorney fee agreement values).

${ }^{42}$ Matthew D. Cain \& Steven Davidoff Solomon, A Great Game: The Dynamics of State Competition and Litigation, 100 IowA L. REv. 465, 469 (2015) (finding that the percentage of large mergers that resulted in shareholder litigation increased from $39.3 \%$ in 2005 to $92.1 \%$ in 2011).

${ }^{43}$ In re Trulia, Inc. Stockholder Litig., 129 A.3d 884, 898 (Del. Ch. 2016) (“[T]he Court will continue to be increasingly vigilant in applying its independent judgment to its caseby-case assessment of the reasonableness of the 'give' and 'get' of [disclosure] settlements ...."). The court specified that disclosure settlements would be disfavored "unless the supplemental disclosures address a plainly material misrepresentation or omission" and any proposed liability release narrowly applies only to disclosure and fiduciary duty claims that have been sufficiently investigated.

${ }^{44}$ See Boilermakers Local 154 Ret. Fund v. Chevron Corp., 73 A.3d 934, 962 (Del. Ch. 2013) (authorizing forum-selection bylaws limiting litigation regarding internal affairs to Delaware); Roberta Romano \& Sarath Sanga, The Private Ordering Solution to Multiforum Shareholder Litigation, 14 J. EMPIRICAL LEGAL STUD. 31, 44 (2017) (finding that forum-selection clauses dramatically increased between 2012-2014, resulting in 746 U.S.-domiciled public corporations adopting exclusive-forum clauses, with ninety-three percent of those selecting Delaware as the exclusive forum).

${ }^{45}$ See Corwin v. KKR Fin. Holdings LLC, 125 A.3d 304, 313 (Del. 2015) ("When the real parties in interest - the disinterested equity owners - can easily protect themselves at the ballot box by simply voting no, the utility of a litigation-intrusive standard of review 
litigation fueled by so-called appraisal arbitrage, and also involving arm's length deals. ${ }^{47}$ That wave was quelled to some extent by amendments to the appraisal statute establishing minimum amounts in controversy, ${ }^{48}$ but to a much greater extent by judicial rulings emphasizing the valuation significance of market transactions (the sale price itself, or share market prices, or both) and effectively limiting recovery to the deal price, or less. ${ }^{49}$

Skepticism about the limits of shareholder litigation, however, is not the same as implacable opposition to such litigation. In Delaware's system of corporate law, representative stockholder plaintiffs, and their lawyers, are a bulwark against misappropriation and electoral manipulation by self-interested directors, officers, and controlling stockholders, and are therefore a critical promoter of efficient, wealth-creating corporate governance. ${ }^{50}$ So despite recognizing deficiencies in Delaware's shareholder

promises more costs to stockholders in the form of litigation rents and inhibitions on risktaking than it promises in terms of benefits to them.").

${ }^{47}$ See Wei Jiang, Tao Li, Danqing Mei \& Randall Thomas, Appraisal: Shareholder Remedy or Litigation Arbitrage?, 59 J. L. \& ECON. 697, 699 (2016) (documenting the evolution of appraisal arbitrage in Delaware from 2000-2014 and finding that the amount of petitions increased from roughly two percent to twenty-five percent of eligible deals).

${ }^{48}$ DEL. CoDE ANN. tit. 8, § 262(h) (2016) (restricting appraisal rights to instances where shareholders seeking appraisal amount to one percent of outstanding shares or \$1 million in merger consideration).

${ }^{48}$ See DFC Global Corp. v. Muirfield Value Partners, 172 A.3d 346, 349 (Del. 2017) (explaining that, in open and arm's length mergers, the "best evidence of fair value [is] the deal price"); Dell, Inc. v. Magnetar Glob. Event Driven Master Fund Ltd., 177 A.3d 1, 30 (Del. 2017) (reinforcing DFC by finding that "Dell's deal price has heavy, if not overriding, probative value" in appraisal proceedings); Verition Partners Master Fund Ltd. v. Aruba Networks, Inc., 210 A.3d 128, 136 (Del. 2019) (giving "important weight to market-tested deal prices" to again award an appraisal value far below that sought by the dissenters and below even the deal price). See also S. Michael Sirkin, Appraisal After Aruba Networks: What Do Jarden, Columbia Pipeline, and Stillwater Mining Teach Us?, 23 M\&A LAWYER 1, 6 (2019) (describing the trend against appraisal arbitrage); Wei Jiang, Tao Li, \& Randall S. Thomas, The Long Rise and Quick Fall of Appraisal Arbitrage (February 28, 2020). Vanderbilt Law Research Paper No. 20-16, available at https://ssrn.com/abstract=3546281 or http://dx.doi.org/10.2139/ssrn.3546281 (finding that the principal reason for the decline in appraisal arbitrage were the appraisal opinions from the Delaware Supreme Court in 2017, cited above).

${ }^{49}$ See generally Leo E. Strine, Jr. \& Lawrence A. Hamermesh, Delaware Corporate Fiduciary Law: Searching for the Optimal Balance, in EvAN J. CRIDDLE, PAUL B. 
litigation system, I have been proud to be part of drafting legislation that prohibited feeshifting charter and bylaw provisions that, while addressing inefficient litigation, could have effectively eliminated shareholder litigation as a check on corporate misbehavior. ${ }^{51}$

\section{Conclusion}

It has been a privilege to have had the opportunity to reflect on over four decades of practicing and teaching Delaware corporate law, and to be able to share my perspective on that opportunity with the rarefied - and, with all affection, nerdy - cohort of students of that field of the law. My experience has been nothing like a study of "towering skyscrapers of rusted girders, internally welded together and containing nothing but wind," 52 and it would not be unreasonable to expect that in the next four decades the subject be at least as challenging.

Miller, AND ROBERT H. SITKOFF, EDS., OXFORD HANDBOOK OF FidUCIARY LAW (Oxford Univ. Press 2019) (explaining through a survey of fiduciary duty doctrine that directors enjoy broad autonomy, but when there may be a conflict of interest, shareholder litigation serves as a check on mismanagement).

${ }^{51}$ See Hamermesh \& Wachter, supra note 40, at 600-01, n.9 (describing 2015 amendments to Sections 102 and 109 of the Delaware General Corporation Law that prohibit fee-shifting provisions that burden stockholder plaintiffs). See also Ashiq Ali \& Brad Nathan, Do Shareholders Benefit from Fee-Shifting Bylaws?, [forthcoming] (finding negative returns associated with release of the Delaware Supreme Court opinion in ATP Tour v. Deutscher Tennis Bund, 91 A.3d 554 (Del. 2014), approving bylaws providing for shifting litigation expenses to plaintiff stockholders who are less than wholly successful in litigation).

52 Bayless Manning, The Shareholder's Appraisal Remedy: An Essay for Frank Coker, 72 YALE L.J. 223 (1962). 